\title{
Public Relations and Image Making for Libraries and the Profession in Nigeria
}

By

IFEANYI J. EZEMA

Nnamdi Azikiwe Library

University of Nigeria - Nsukka

\begin{abstract}
The library profession has gone through several stages in its development in Nigeria. Librarians have always agitated for improvement in library development in the country and government has often paid lip services towards genuine desire for library development. Though librarians have been given a professional status through an enabling law, not much has been done for the implementation of this status accorded them. This paper identifies several factors that have affected the rapid growth of the profession. It challenges the librarians, Nigerian Library Association and the National Library of Nigeria to combat these factors through sustainable public relations.
\end{abstract}

\section{Introduction}

The library profession in Nigeria has passed through precarious stages in its development. The West African Library Association pioneered the efforts of bringing together librarians in West Africa until when it was renamed Federation of West African Library Association. With this development, each member country was encouraged to form national association. This resulted in the formation of Nigerian Library Association between December 15 and 17, 1962 with the late John Harris as its first Chairman. The constitution establishing the Nigerian Library Association (NLA) was adopted at its Annual General Meeting (AGM) held on $12^{\text {th }}$ April, 1964 (Abifarin; 1996).

A booster was given to the association with the establishment of National Library of Nigeria in 1970 through the National Library Decree No. 29. Though the decree did not provide professional status for librarians, it increased public interest in library service and librarians. In addition, it marked a genuine beginning of government interest in the development of libraries in the country. Since among its objectives was the establishment and maintenance of branch libraries in each state of the federation, the decree has contributed immensely in the growth of library service in the country.

This latest development offered librarians opportunities to agitate for a professional status. This was the problem of librarians in the country until the promulgation of the decree No. 12 of 1995, which provide for the librarians registration council with the following functions:

a. Determining who are librarians for the purpose of the decree;

b. Determining what standards of knowledge and skills are to be attained by persons seeking to become registered as librarians in this Decree referred to as "the profession" and reviewing those standards from time to time as circumstance may require;

c. Securing in accordance with the provision of the Decree the establishment and maintenance of a register of profession, and the publication from time to time the list of such person;

d. Maintaining discipline within the profession in accordance with the decree; and

e. Performing such other functions as may be conferred upon the council by this decree.

This decree lay to rest the problem of professional status among librarians.

The council has been inaugurated and has started registering professional members. However due to some logistics and administrative bottlenecks especially from the government, not much has been achieved beyond this effort. The future of the profession is dependent on the ability of the council to perform these functions the decree has conferred on it.

\section{The Image Problem}

The professional image of the librarian has been of great concern to those in the profession and has generated a lot of literature contributors such as (Fasanya, 1984; Neil, 1991; Kantumoya, 1993; Anafulu, 1995; Aharony, 2006) describe librarians using horrifying words. Some described librarians as never - do - wells, harsh, reserved, strict, subdued etc. Others looked at them as book warmers, keepers of books, gentle, easy going, etc. In academic environments, faculty staff that are colleagues of librarians pay little or no attention to them. The are seen as people whose only duty is to shelve books. In other related works the professional image of a librarian is regarded as feminine and powerless profession and possesses knowledge limited only to the physical library (Harris and Wilkinson, 2001; Fagan, 2002; Mendelovis, 2003). A study conducted by Fourie 
(2004) revealed that librarians are perceived as passive, conservative, introspective, introverted, lack self confidence and exhibiting poor international skills.

In his study of librarians' image, Kantumoya (1993) regretted that government of the various countries were responsible for the image problem. He blamed governments for the underserved neglect of library services in most developing countries. Neil (1991) corroborated Kantumoya's findings but quickly observed that librarians have some share of the blame on the image problem. He laments mediocrity and lack of vision among many librarians that affect their self-esteems. Anafulu (1995) observed that where some academic librarians present themselves as "errand boys" to the chief executive and other principal officers of the institution. He points out that a librarian who kow-tows to the chief executive while massaging the egos of the principal officers is dragging his image and his career to the mud.

Harris (1986) and Abifarin (1996) link the image problem of librarian to the way Africans view librarians. They note that while in developed countries of Europe and America people look at the library as a repository of knowledge, which add much value to their every day life, an average African views the library as not only irrelevant but also as an elitist institution inaccessible by all but the most privileged in the society. They complain that the librarians are not equally helping matters as they do nothing to promote reading culture. Thus, librarians leave the society to define their job for them.

An investigation carried out by Morrisey and Case (1988) portrayed the negative attitude of librarians on themselves as a demanding factor on their image. The investigation showed that even though clientele and the general public hold male librarians at a high esteem, they (librarians) still maintain negative attitude towards the profession. The investigation also revealed that most of the library users do not know who a librarian is. Since most the professional aspect of the job is done behind the scene, the supporting staff who serve the readers are the librarian they know. This suggests that librarians' rating revolve round these supporting staff. Even the porters who perform security job in the library are librarians. This explains why the student surveyed by Ajidahum (1997) were unable to identify who a librarian is. To the student anybody who works in the library is a librarian. Hence, the student doubt whether librarians are university graduates and would not want to take up career in librarianship.
For a profession to grow, it must ensure a good image so that younger ones will be attracted. While it is true that the government of Nigeria has always paid lip services to library development, those in the profession should make concerted efforts to promote the image of profession. It is not in the best interest of librarians to remain aloof while the profession continues to suffer. It is time a radical approach was devised to mitigate the image problem.

\section{Public Relations and the Library}

The Institute of Public Relations (UK) cited in Igbokwe (1997) defines public relations as "the deliberate planned and sustained efforts to establish and maintain mutual understanding between an organization and its public". Hence Carlson (1972) however, explains public relations as an organized effort to communicate information and modify attitudes and behaviours on behalf of a client or cause. The aim of such effort is to bring to an organization the support and cooperation it requires in order to accomplish its objectives. For an organization to achieve this, different public relation techniques have to be employed.

Unamka (2000) identifies the following areas where public relations can be applied:

i. Civic community relations;

ii. Government relations;

iii. Press relations

iv. Inter-firm relations

v. Relations with the general public

However, Harrison and Beenham (1985) summarized library public relations under four cardinal facets.

i. Relations with users

ii. Relations with potential users

iii. Relations with the library staff

The neglect of any of these areas will affect the image of the organization negatively.

Libraries have traditional method of promoting their service (public awareness services) that are inform of display, book fairs, shelve guide, selective dissemination of information among others. In addition to this the library often adopts some other strategies to promote the public relation within the library. However, the ability of the librarian-in-charge to use his professional competence largely determines the success or otherwise of such strategies. Anafulu (1995) is of the view that a shrewd librarian should employ good public relation to earn the confidence of the chief executive of the funding body without sacrificing his reputation. Such librarian must however posses good qualities such as outstanding communicative skill which will facilitate the presentation of the library's problems, enjoy extra institutional prestige arising from professional appointment and scholarly publications which 
contributes to his high esteem and above all the ability to be relevant professionally and the managerial skills for efficiency of the library.

\section{Sustainable Public Relations for Library Profession - The Way Forward}

Hyman (1982) has advised that: "We need to stop doing battle in the last year's war, to stop worrying about what they (the public) think we look like and get out the message of what we do - the wide variety of skills we posses and the services we can provide". The bright future of library profession lies in the hands of the practitioners themselves. There is a limit to what government can do. The members of the profession have a lot to do to make the profession grow above others. Radical measures from different angles that will improve the image of the profession especially by the Nigerian Library Association (NLA) the practitioners and the National Library of Nigeria (NL) should be adopted.

\section{The Nigerian Library Association}

The NLA should go for a retreat to reflect on what makes an ideal profession. Perhaps it could examine Hanks and Schmist (1980) suggestions stated below:

i. It must have its own body of knowledge and techniques appropriate to it.

ii. It must have recognized professional training.

iii. Its members should belong to the professional association, which aims at developing and controlling the profession.

iv. It must have a code of ethics for regulating the conduct of members.

v. It must be service oriented to the society.

vi. It must generate its own literature to ensure intellectual development of its field.

A critical appraisal of these criteria is very crucial for NLA to reposition the body towards attaining true professional status. The mere recognition through statute is not enough - the profession has to live above boards.

The NLA should try and break the political circles through meaningful diplomacy. Interestingly, Nigeria is now under a democratic rule where political and legal means should be employed to achieve the desired objectives.

It can borrow a leaf from American Library Association, which created a committee for State and Federal relations with the aim of promoting library services in America. One of the greatest achievements of the committee as reported by Stevenson (1965) was the passage of library service act of 1956. the act provided $\$ 37.5$ million on the matching basis for library development in rural areas over a 5 year period. This act, no doubt improved library services in rural America immensely. The NLA, through similar committees can sponsor bills aimed at developing library services in the country. Very many debilitating problems of the profession such as formulation of National Library and Information Policy, full implementation of Librarians' Registration Council of Nigeria, establishment of public libraries in rural areas among others could be given a political solution.

The press is another powerful agency in promoting public relations and the image of any profession. The NLA should involve the media outfits to contribute to the image making of the profession. Effort should be made to ensure that all NLA activities given wide press coverage. The Annual General Meetings (AGMs) of NLA and other programmes concerned with the profession should receive wide publicity in both print and electronic media. In addition, the NLA should sponsor library related jingles on radios and television to conscientize the public on the indispensable role of the library on the individual and the over all national development.

The NLA can sponsor phone in programmes on network services of Radio Nigeria and Nigerian Television Authority (NTA) to educate the general public on the relevance of libraries in the National Development. This should be given a priority bearing in mind the dynamic roles of radio and television in information dissemination. It should put politicians, the presidency and other eminent personalities in the country in most of its activities.

Other members of the wider society particularly those who show interest in the profession (renowned authors, publishers, editors, members of the academia etc) should be conferred with fellows of the association. This will no doubt boost the image of the profession.

\section{The National Library of Nigeria}

The National Library of Nigeria (NLN) as the apex library in the country has a major role to play in promoting the image of the profession. The national library decree No. 29 of 1970 assigned it among others, advisory role to other libraries in the country. This role could be employed in canvassing for the improved library facilities in the country, development of more public libraries in the country, and putting up suggestions on how to tackle problems, which militate against promotion of the image of the profession.

The NLN can promote the image of the librarians by developing cooperation with Radio Nigeria and NTA on issues of public relations programmes. Being agencies of Federal Government of Nigeria they could organizes enlightenment programmes on 
raido and television aimed at educating the public on the relevance of library and information science to their lives and the nation at large. The NLN on its own may wish to offer library services to both media houses to strengthen cooperation among them. This type of cooperation will help greatly in promoting the image of library and the library profession.

The NLN contribute in boosting the image of the profession through sponsoring of conferences and seminars whose major themes should be on public relations and the library profession. During such seminars, eminent scholars should be invited to such shows and workshops. The participants should be drawn from practicing librarians, library and information science educators, students of library and information science and other members of the public interested in the growth of the profession.

\section{The Role of the Librarians}

Practicing librarians and library and information science educators should not leave the issue of public relations for the NLA and NLN alone. They need to be involved actively in the formation of the image of the profession. There has to be a change of attitude towards the profession. Librarians have to assert themselves before anybody and anywhere believing that those in other professions are not better than them. Today information leads the world and anybody in the information industry should not have any cause to regret provided he has confidence in himself.

Librarians should move into active politics once the opportunity is ripe for it. They should join political parties and contest for elective positions or at least be active members of political parties. A critical observation on the politics of the country will reveal clearly that librarians are nowhere. It is a fact that any politician protects his interest first, the interest of his constituency second, the interest of his profession follows before any other thing. By engaging in active politics, librarians will reposition themselves in the national decision making process where they can project the profession to the society.

Librarian should continue to maintain active membership of trade unions. For example, the librarian in higher institution of learning should be an active members of Academic Staff Union of Universities (ASSU), Academic Staff Union of Polytechnic (ASUP) or College of Education Academic State Union (COEASU) as the case may be. He should also contest election into the executive council of such unions or serve as members of the union's committee where possible. Being an executive council member, he should be in a position to launder his professional image and influence decisions in favour of the profession. Each time representation is made to government or its agency on the development of the parent body, he should the to it the the problem of the library is reflected as much as it is possible. A colleague in public, special and national libraries should also be a good ambassador of the profession in his place of work.

Library and information science educators should liaise with supervising bodies of their institutions to review the course programmes in the departments. Two or more courses on library public relations should be introduced into their programmes. This will equip the students better to face the challenges ahead of them when they come into the field.

\section{Conclusion}

Library profession has undergone through slow but steady development in Nigeria due some problems from the society. The government and the practitioners, if the Nigerian Library Association (NLA), the National Library of Nigeria and those in the profession campaign vigorously through public enlightenment, the image problem of library profession in Nigeria would be a thing of the past. 


\section{References}

Aharony, N. (2006). The Librarian and the Information Scientist: Different Perceptions among Israeli Information Science Students. Library and Information Science Research. $28,235-247$

Abifarin, A (1996). The Library Profession in Nigeria: an Appraisal. Nigerian Journal of Library and Information Service. 1(1), 45 - 51

Agaja, J. A. (1997). Librarianship as a profession in Nigeria. Explanation in the $21^{\text {st }}$ Century. Library Bulletin: Nigeria Univesity Library System. 2 (1\& 2), 94 - 99.

Ajidahum, C. O. (1997). Students' perception of librarians of the Ondo State. Library Bulletin: University Library System 2 (1 \& 2) 77 - 83

Anafulu, J. C. (1995). The University Library and the University administration. Library Bulletin: University Library System 1 (1) 1 - 17

Fagan, J. (2002). Students' perceptions of academic librarians. Reference Librarian, 78, $131-148$

Carlson, R. O. (1972). Public Relations in International Encyclopedia of Social Sciences. Vol. 13 and 14. London: Macmillan 208 217.

Fasanya, J. O. (1984). The image of the librarian. Lagos Librarian 11(1\&2) $54-55$. 